\title{
KOMPLEMENTARNY CHARAKTER MIŁOSIERDZIA CHRZEŚCIJAŃSKIEGO I SPRAWIEDLIWOŚCI SPOŁECZNEJ W MISJI KOŚCIOŁA JAKO NAUCZYCIELA, DEPOZYTARIUSZA I SZAFARZA MIŁOSIERDZIA
}

\section{MlŁOSIERDZIE - WOBEC TEGO, CO „TU I TERAZ”}

Byliśmy przyzwyczajeni do znajdowania w dokumentach papieskich pobożnych cytatów z Pisma Świętego względnie wypowiedzi Ojców Kościoła. Aż tu nagle wielkie zdziwienie: w tegorocznych słowach Franciszka skierowanych z okazji 50. Światowego Dnia Środków Społecznego Przekazu znalazł się cytat z Williama Shakespeare'a, prawdopodobnie inspirowany upamiętnieniem śmierci poety przed 300 laty. Parafrazując, można go oddać następująco: „Dla miłosierdzia nikt przymusu nie ma;

* Ks. Marek Filipczuk - kapłan diecezji warszawsko-praskiej, teolog moralista, doktor nauk teologicznych w zakresie teologii moralnej, wykładowca teologii moralnej na Wydziale Teologicznym Uniwersytetu Kardynała Stefana Wyszyńskiego w Warszawie (filipczuk17@gmail.com). 
Ono jak kropla niebieskiego deszczu spływa na ziemię, dwakroć błogosławi tego, co daje, i tego, co bierze"'.

Niezwykły jubileusz, oficjalnie zwołany bullą „Misericordiae vultus” (11 VI 2015 r.) Roku Świętego Miłosierdzia dobiegł końca. Ten Rok Święty był pierwszym, który nie został uzasadniony okrągłą rocznicą historii zbawienia, lecz szczególnym atrybutem Boga. Rozpoczął się 8 grudnia 2015 r. wraz z otwarciem Drzwi Świętych w Bazylice Świętego Piotra i trwał do uroczystości Chrystusa Króla pod koniec listopada 2016 r. Data otwarcia została wyraźnie wybrana przez papieża w odniesieniu do Soboru Watykańskiego II, który zakończył się pięćdziesiąt lat temu. „Kościół czuje potrzebę podtrzymywania żywej pamięci o tym wydarzeniu. Zaczynał się nowy etap jego historii. Ojcowie zgromadzeni na Soborze czuli silną, jak prawdziwy powiew Ducha Świętego, potrzebę mówienia o Bogu ludziom swoich czasów w sposób bardziej zrozumiały. Po obaleniu murów, które przez zbyt długi czas zamykały Kościół w uprzywilejowanej twierdzy, nadszedł czas, by głosić Ewangelię w nowy sposób”2. Już samo powiązanie Roku Świętego z Soborem Watykańskim II, opierające się na ekumenicznych sygnałach pochodzących od tego Soboru, było znaczące. Korespondował z nim także fakt, że jubileusz nie był obchodzony tylko w samym Rzymie, ale we wszystkich Kościołach lokalnych na świecie, co służyło duszpasterskiej odnowie całego Kościoła.

INTENCJE JUBILEUSZU MIKOSIERDZIA WYKRACZAJĄCE POZA RAMY ROKU ŚWIĘTEGO

Wydaje się, że papież Franciszek chciał wysunąć miłosierdzie na pierwszy plan, czyniąc je tym samym czymś wyrazistym, i powierzyć je Kościołowi XXI wieku jako ważny motyw jego posłannictwa. Oczywiście nie jest to nowy problem. W praktyce jednak jest on często postrzegany jako jeden z wielu atrybutów Boga. Walter Kasper wydał w roku 2012 książkę Miłosierdzie. Podstawowe pojęcia Ewangelii - klucz życia chrześci-

1 Por. W. Shakespeare, Kupiec wenecki, tł. S. Barańczak, Kraków 2004, akt IV, scena 1 .

2 Franciszek, Misericordiae vultus. Bulla ogłaszająca Nadzwyczajny Jubileusz Miłosierdzia, Watykan 2015, nr 4 [dalej skrót: MV]. 
jańskiego. Określa w niej miłosierdzie „mocno zaniedbanym tematem”, który „w encyklopediach oraz $\mathrm{w}$ podręcznikach teologii dogmatycznej w najlepszym razie występuje na marginesie"3. Kardynał Kasper opowiadał później, jak w dniach konklawe (2013) miał swój pokój w pensjonacie Santa Marta na tym samym piętrze co kardynał Bergoglio SJ. Gdy pewnego wieczoru spotkał arcybiskupa Buenos Aires, podarował mu świeżo wydrukowaną hiszpańską edycję swego dzieła. Bergoglio wziął je i powiedział: „Misericordia questo il nome del nostro Deo - Miłosierdzie, to jest imię naszego Boga. Bez niego wszyscy byśmy zginęli”. Prawdopodobnie przeczytał tę książkę jeszcze podczas konklawe.

Z pewnością papież Franciszek odkrył temat miłosierdzia znacznie wcześniej. W jubileuszowej bulli wspomina, że już jako biskup wybrał sobie zawołanie: „miserando motto at que eligendo", nawiązujące do powołania Mateusza, podczas którego Jezus przyglądał się z miłosierną miłością temu celnikowi i wezwał go ${ }^{4}$. Ponadto, papieże ostatnich 50 lat konsekwentnie wybierali miłosierdzie jako ważny temat swojego nauczania. Sam Franciszek wspomina o tym. Podczas otwarcia Soboru Watykańskiego II papież Jan XXIII powiedział, że Kościół wielokrotnie potępiał błędy, czasem zbyt surowo. „Dziś jednakże Oblubienica Chrystusa woli posługiwać się raczej lekarstwem miłosierdzia aniżeli orężem surowości”. Paweł VI podkreślił na zakończenie Vaticanum II, że „religią naszego Soboru była przede wszystkim miłość"6. Prawie zapomniana jest druga encyklika Jana Pawła II, która wówczas spowodowała duże zaskoczenie, a która poświęcona została miłosierdziu: „Dives in misericordia” (1980). W niej zostało powiedziane, że „miłosierdzie (...) jest najbardziej zaskakującym przymiotem Stwórcy i Odkupiciela”.

Cenione są także przez Franciszka obie encykliki papieża Benedykta XVI o miłości: „Deus caritas est” (2006) i jego encyklika społeczna „Caritas in veritate" (2009), w której wskazał on w miłości jako podstawowej zasadzie nowe podejście dla katolickiej nauki społecznej i tym samym

3 W. Kasper, Barmherzigkeit. Grundbegriff des Evangeliums - Schlüssel christlichen Lebens, Freiburg i. Br. 2012.

4 Por. MV 8.

${ }^{5}$ MV 4.

6 Tamże.

${ }^{7}$ MV 11. 
sprawiedliwości nie postrzega jako jedynego fundamentu․ Zwyczajnie zatem kontynuuje papież dziedzictwo swoich poprzedników. Poprzez ogłoszenie Roku Świętego zagadnienie miłosierdzia ma szansę jednak bardziej się rozwijać i mieć większy wpływ na głębię życia chrześcijan.

„Misericordiae vultus” rozpoczyna się programowymi słowami, które dają tej bulli nazwę: „Jezus Chrystus jest obliczem miłosierdzia Ojca. Wydaje się, iż tajemnica wiary chrześcijańskiej znajduje w tym słowie swoją syntezę" . Na koniec papieskiego tekstu pada natomiast stwierdzenie: „Kościół wie, że jego pierwszym zadaniem, przede wszystkim w takim momencie jak obecny, pełnym wielkich nadziei i silnych sprzeczności, jest wprowadzenie wszystkich [więc najwyraźniej nie tylko chrześcijan; zob. MV 5; 12] w wielką tajemnicę miłosierdzia Boga przez kontemplowanie oblicza Chrystusa"10. Te dwie sentencje, napinające łuk między początkiem i końcem „Misericordiae vultus”, nie tylko przenoszą miłosierdzie do centrum wiary chrześcijańskiej, lecz także podkreślają jasno, że przede wszystkim chodzi o miłosierdzie Boga, a ono tak naprawdę objawia się w pełni w osobie Jezusa Chrystusa. Gdyż to właśnie: „Jezus z Nazaretu swoimi słowami, gestami i całą swoją osobą objawia miłosierdzie Boga"11.

Papież Franciszek wydobywa za każdym razem, używając coraz to nowych określeń, prymat miłości miłosiernej. Miłosierdzie jest „najwyższym i ostatecznym aktem, w którym Bóg wychodzi nam na spotkanie" (MV 2); ono jest „W Piśmie Świętym kluczowym słowem na określenie postępowania Boga w stosunku do nas” (MV 9); ono jest „istotą Ewangelii oraz naszej wiary” (MV 9), jest „bijącym sercem Ewangelii” (MV 12); ono jest „podstawowym wymiarem misji Jezusa” (MV 20).

Z tego wynika dla Kościoła: Miłosierdzie jest „architrawem”, który wspiera jego życie (MV10); jego "pierwszą prawdą" (MV 12), a „prymat miłosierdzia [jest] regułą życia” dla uczniów Chrystusa (MV 20). Zatem można, podsumowując, powiedzieć: Miłosierdzie jest według Franciszka „drogą, która łączy Boga z człowiekiem, ponieważ otwiera serce na nadzieję, że będziemy kochani na zawsze, pomimo ograniczenia, jakim jest

\footnotetext{
${ }^{8}$ Zob. Evangelii Gaudium 7 lub Laudato Sì w różnych miejscach.

9 MV 1.

${ }^{10}$ MV 25.

${ }^{11}$ MV 1.
} 
nasz grzech” (MV 2). „Miłosierdzie Boga nie jest więc jakąś abstrakcyjną ideą, ale konkretnym faktem, przez który On objawia swoją miłość podobną do miłości ojca i matki, których aż do trzewi porusza los własnego dziecka. W tym przypadku naprawdę można mówić o miłości głęboko zakorzenionej”(MV 6) ${ }^{12}$. Słowo „miłosierdzie” „objawia Przenajświętszą Trójcę"(MV 2).

Gdy Franciszek tak mocno obstaje przy miłosierdziu jako kwintesencji wiary chrześcijańskiej, nie chce przez to jedynie przywołać w pamięci tej ponadczasowo ważnej prawdy. On czerpie w tym zakresie inspirację z logiki diagnozującej czas. Okropności XX wieku, ale także bezlitosny terroryzm początku wieku XXI, nędza głodujących dzieci, przepływ uchodźców, klęski żywiołowe i inne okropności są „znakami czasu”, które dzisiaj potęgują „wołanie o miłosierdzie”, jak zauważył Walter Kasper ${ }^{13}$. Dlatego Franciszek mógł wytyczyć poniższy cel Roku Jubileuszowego: „Są chwile, w których jeszcze mocniej jesteśmy wzywani, aby utkwić wzrok w miłosierdziu, byśmy sami stali się skutecznym znakiem działania Ojca. Z tego właśnie powodu ogłosiłem Nadzwyczajny Jubileusz Miłosierdzia jako pełen łaski czas dla Kościoła, aby świadectwo wierzących stało się jeszcze mocniejsze i skuteczniejsze" (MV 3). Oczywiście świadectwo takie nie powinno zgasnąć wraz z końcem Roku Świętego. Chodzi przecież o fundamentalną odnowę Kościoła. „Bardzo pragnę, aby nadchodzące lata były przepojone miłosierdziem i byśmy wychodzili na spotkanie każdej osoby, niosąc dobroć i czułość Boga! Do wszystkich, tak wierzących, jak i tych, którzy są daleko, niech dotrze balsam miłosierdzia jako znak królestwa Bożego, które jest już obecne pośród nas" (MV 5).

Niektóre z tych znaków czasu omawia papież bardziej szczegółowo w swojej encyklice „Laudato Sì (2015). Na kartach bulli podejmuje to, co powiedział w jednym ze swoich pierwszych wywiadów i co postrzega jako szczególnie naglące: „Widzę bardzo wyraźnie, że to, czego Kościół dzisiaj potrzebuje, to zdolność leczenia ran i ogrzewania ludzkich serc -

12 Ani powszechna idea Boga, owego nieporuszonego Poruszyciela, ani majestatyczny Prawodawca; ani też istota tego, co piękne, prawdziwe i dobre, nawet nie pra-zasada bytu jest punktem odniesienia etyki Jezusa, lecz osobowy Bóg Biblii. Por. T. Söding, Die Verkündigung Jesu - Ereignis und Erinnerung, Freiburg i. Br. 2011, s. 581.

13 Por. W. Kasper, Barmherzigkeit. Grundbegriff des Evangeliums - Schlüssel christlichen Lebens, dz. cyt., s. 11. 
bliskość i głęboka więź. Postrzegam Kościół jako szpital polowy po bitwie. Ciężko rannego nie pyta się o poziom cholesterolu lub wysoki poziom cukru. Trzeba leczyć rany. Potem możemy rozmawiać o wszystkim innym. Goić rany, goić rany... Trzeba zaczynać u samego dołu (u korzeni)"14. W zaproszeniu do świętowania Roku Jubileuszowego papież jeszcze to wzmacnia: „W tym Jubileuszu Kościół zostanie jeszcze bardziej wezwany do leczenia tych ran, do opatrywania ich olejem kojenia, do opatrywania ich miłosierdziem oraz do leczenia ich solidarnością i należną uwagą"15.

\section{DLACZEGO RELIGIJNE UZASADNIENIE DLA MIŁOSIERDZIA?}

Znane krytyczne pytanie brzmi: dlaczego właściwie łączyć miłosierne relacje międzyludzkie $\mathrm{z}$ Bogiem i religią? Albo inaczej mówiąc: co wspólnego ma otwartość na bliźniego z Bogiem, co współżycie międzyludzkie z religią? Czy pracownicy socjalni nie powinni podejmować wszelkich starań, by zapewnić dobrą pracę jako poszczególne osoby oraz razem w instytucjach? Czy nie chodzi przede wszystkim o skuteczną i trwałą pomoc - gdziekolwiek i jakkolwiek jest to możliwe? Czy religijność (pobożność) i mowa o Bogu są jedynie jakimś rodzajem „pobożnego sosu”, którym polewa się całą kościelną pracę socjalną, która w zasadzie mogłaby się okazać zbędna?

$\mathrm{Z}$ pomocą przychodzi nam piśmiennictwo czasów apostolskich Kościoła. Tak zwane „uniżenie Syna Bożego”, który istniał w preegzystencji na równi z Bogiem, stało się kluczem Pawłowego opisu dzieła odkupienia, które kieruje on do mieszkańców Filippi. Całkiem możliwe, że motyw uniżenia ma swoje psychologicznie uwarunkowanie - Paweł pisze list $\mathrm{w}$ więzieniu. W samym liście nie ma jednak na to wystarczających dowodów. Apostoł stwierdza najpierw, że Chrystus istniał w postaci Bożej, lecz nie skorzystał ze sposobności, aby na równi być z Bogiem (Flp 2,6). Ogołacając samego siebie, poprzez uniżenie stał się człowiekiem („podobnym do ludzi”, „w zewnętrznym przejawie uznany za człowieka”

${ }^{14}$ Wywiad z papieżem Franciszkiem dla czasopism jezuickich przeprowadzony przez Antonio Spadaro SJ 19 sierpnia 2013r., www.stimmen-der-zeit.de/zeitschrift/online_exklusiv/details_html?k_beitrag=3906412 [dostęp: 06.12.2016].

${ }^{15}$ MV 15. 
- Flp 2,7). Mówiąc inaczej, Chrystus podjął decyzję o przejściu z drogi błogosławieństwa, a więc z Bożej obecności, na drogę przekleństwa, na którą poprzez przekroczenie Prawa wkroczył każdy człowiek. Jezus stał się w pełni człowiekiem, doświadczając śmierci krzyżowej. Bóg jednak nie pozostawił Go w stanie śmierci, lecz wywyższył Go ponad wszelkie rodzaje istot duchowych, „aby na imię Jezusa zgięło się każde kolano istot niebieskich i ziemskich, i podziemnych" (Flp 2,10). W ten sposób kara za ludzki grzech została odpokutowana. Bóg okazał się w pełni miłosierny i absolutnie sprawiedliwy ${ }^{16}$.

Takie działanie Boga uświadamia nam, że Jego miłość jest zupełnie darmowa! Żaden ludzki wysiłek nie sprawi, że On nas pokocha, ponieważ nie potrzebuje do tego żadnych naszych zasług! Nie możemy zrobić nic, by Bóg kochał nas bardziej, gdyż kocha najbardziej. Nie możemy też zrobić nic, by kochał nas mniej, gdyż On z natury swojej jest miłością i nie potrafi istnieć inaczej, jak tylko kochając! Bóg kocha ludzi całą swoją istotą, zupełnie bezwarunkowo i całkowicie za darmo. Kocha nie dlatego, że zachowujemy przykazania, ale ponieważ jest Ojcem. Kocha nie dlatego, że staramy się być święci, ale dlatego że On jest święty. Kocha nie dlatego, że my unikamy grzechu, ale ponieważ On jest bez grzechu ${ }^{17}$.

Ten przykład pokazuje, dlaczego dla chrześcijanina to fundamentalne doświadczenie bycia bezwarunkowo kochanym i akceptowanym przez Boga jest tak istotne. Współcześnie tak popularne, ale także krytycznie kwestionowane miłosierdzie ma w chrześcijańskim zakorzenieniu w wierze solidny, nośny, trwały i motywujący fundament - i dotyczy to wszystkich: profesjonalistów oraz wolontariuszy w taki sam sposób. Przedstawmy kilka powodów, które to doświadczenie czynią zrozumiałym:

- Bez wezwania Jezusa do miłosiernego działania moglibyśmy zapomnieć, że do każdej potrzeby przynależy konkretna ludzka twarz.

${ }^{16}$ Por. Jan Paweł II, Dives in misericordia. Encyklika o Bożym miłosierdziu, Watykan 1980, nr 6. Zob. także: K. Matwiejuk, Bóg bogaty w miłosierdzie w świetle pierwszej modlitwy eucharystycznej o tajemnicy pojednania, „Warszawskie Studia Teologiczne” 2016, nr 2, s. 24-37.

17 Por. tamże, nr 5. Zob. także: K. Romaniuk, Biblijny traktat o miłosierdziu, Ząbki 2004, s. 19-34. 
- Bez zakotwiczenia własnej samodzielności w miłości Boga mogłoby się zdarzyć, że ze względu na zróżnicowane potrzeby w świecie zabrakłoby nam sił do efektywnej pomocy.

- Bez osobistego spotkania z Bogiem mogłoby się okazać, że kontakt z obcym cierpieniem czyniłby nas coraz bardziej oschłym i niezdolnym do współodczuwania.

- Bez świadomości o istnieniu Boga i Jego czystej i świętej troski o nas grzeszników mogłoby się okazać, że stajemy się zgorzkniali i nieprzystępni, gdy zawodzą społeczne uznanie i publiczna pochwała.

- I wreszcie: bez Boga jest chyba - należy sformułować to bardzo ostrożnie - zupełnie niemożliwe prosić ludzi o wrogich poglądach o dobro lub im je czynić18.

W tym momencie dotykamy jednego z wyzwań, które ostatecznie także dzisiaj staje przed człowiekiem świeckim: jak może się to dokonać - mnie samego „pozostawić”, aby stać się wolnym dla człowieka u mojego boku, dla którego mogę być pomocnikiem, pomocnicą, przynajmniej tymczasowo? Jak to możliwe - nie być w ciągłym strachu o siebie i do tego doświadczyć radości i wewnętrznego spełnienia w spotkaniu z innymi? To rodzi pytanie: z jakiego źródła czerpie i syci się ostatecznie samorozumienie człowieka. Wydaje się, że istnieje coś więcej niż tylko ta jedna etyczna alternatywa: heteronomia jednej strony wobec samostanowienia z drugiej; zewnętrznie narzucona („wytresowana”) moralność przeciwko wysoko cenionej „etyce samorozwoju” ${ }^{19}$.

Istnieje oczywiście życie, które właśnie przez swoją zdolność do utraty siebie dla innych może w swej intensywności i dobroci się pogłębiać. Biografia św. Elżbiety Węgierskiej jest tego przykładem: „drugim okiem”, okiem religijności „widać lepiej!”, przynajmniej więcej niż się sądzi, bez zamykania siebie w realiach tego świata. Miłosierne działanie ma swoją oczywistość, której nie da się wyprowadzić jedynie racjonalnie. Są także ludzie, wiemy o tym doskonale, którzy są miłosierni z powodów

18 Por. Jan Paweł II, Dives in misericordia, dz. cyt., nr 7, 14.

19 Por. tamże, nr 14. 
niereligijnych, humanistycznych i żyją miłosiernie. Z pewnością należy to uszanować, a nawet więcej - uznać ${ }^{20}$.

Wierzący i niewierzący ludzi powinni oczywiście sobie nawzajem pomagać, aby ich odpowiednie „źródła miłosierdzia” nie wysychały! Co więcej, ci ludzie, zgodnie z przekazem Pisma Świętego, - często o tym nie wiedząc (anonimowi chrześcijanie) - są niedaleko od Ewangelii. Potwierdza to ważna perykopa Mt 25,31-46 o sądzie ostatecznym. Tam uznanymi przez Sędziego czasów ostatecznych są ci, którzy Chrystusa w ogóle nie znali - a jednak służyli Mu w tajemniczy sposób w tych najmniejszych, cierpiących i potrzebujących.

\section{JAK MIŁOSIERDZIE I SPRAWIEDLIWOŚĆ SĄ ZE SOBĄ POWIĄZANE?}

Miłosierdzie ma dzisiaj niewielki popyt. Słowo kluczowe dzisiejszego odczucia społecznego brzmi: sprawiedliwość. „Muszę domagać się swoich praw!”, „To należy się mi ustawowo!”. Nic przeciwko prawom. Wszystko jest w porządku, jeśli podstawowe prawa np. osób niepełnosprawnych czy też dzieci są ustawowo zapewnione. Jest dobrze, gdy można bronić się w sądzie przed arbitralnością i dyskryminacją. Ale każdy wgłębiający się w temat przyzna: jedynie dzięki paragrafom nasz świat nie będzie bardziej ludzki. Oprócz sprawiedliwości potrzebujemy miłosierdzia, potrzebujemy miłości, która chce zwyczajnie dobra dla sąsiada/bliźniego nawet wówczas, gdy nie otrzyma żadnego wynagrodzenia i żadna sankcja prawna jej nie egzekwuje. Jak cenna jest łaska/litość/zmiłowanie, każdy może sobie najlepiej przeliterować, gdy wyobrazi sobie siebie w rękach bezwzględnego człowieka ${ }^{21}$.

Problemem jest to, że sprawiedliwości można żądać. Miłosierdzia nie. „Ono spada - parafrazując Shakespeare’a - z nieba, jak odświeżający deszcz.... Dokładnie tu tkwi problem: sprawiedliwe działanie jest obo-

${ }^{20}$ Por. tamże, nr 12. Zob. Benedykt XVI, Godność człowieka, wspólne dobro, pomocniczość i solidarność. Przemówienie do uczestników sesji plenarnej Papieskiej Akademii Nauk Społecznych. Rzym, 3 maja 2008 r.

${ }^{21}$ Por. Jan Paweł II, Dives in misericordia, dz. cyt., nr 12 i 14. Na temat relacji miłosierdzie-sprawiedliwość zob. S. Krajski, Dzieci Abrahama. I sprawiedliwość, i miłosierdzie, „Więź" 2016, nr 2, s. 74-80. 
wiązkiem, miłosierdzie natomiast najwyraźniej nie - czy może jednak? Sprawiedliwe działanie jest etycznym obowiązkiem, miłosierdzie natomiast najwyraźniej nie - czy jednak także? Za sprawiedliwość odpowiedzialni są radcy prawni, sędziowie i obrońcy (adwokaci), biura pomocy społecznej. Kto jest odpowiedzialny za miłosierdzie?22

Gotowość do miłosiernego działania wobec innych ma tam szansę, gdzie ja sam doznałem na własnym ciele chociaż raz miłosierdzia. To jest prawie jak w przypadku wymogu przydatności do zawodu społecznego. By z lekkim przerostem powiedzieć: Miłosierdzia nie można się wyuczyć, jego się doświadcza - i topnieje stopniowo lęk, że w dłuższej perspektywie przez rezygnację z osobistych roszczeń zaniedbamy siebie. Tak, niewymuszone poczuciem winy, solidarne zwrócenie się do bliźniego daje radość i wewnętrzne spełnienie, czasami natychmiast, czasami dopiero po fakcie, „cicho”, ale w sposób zrównoważony.

Pojęcie „miłosierdzie”, które papież Franciszek przedstawia światu wraz z tematycznym rokiem, ma również bardzo aktualny wymiar polityczny. Widać to bardzo wyraźnie w traktowaniu kwestii uchodźców. Pamięć o miłosiernej, a więc niezawinionej solidarności w obliczu konkretnego nieszczęścia bliźnich powstrzymuje nas przed wpadnięciem w „pułapki ideologii” - bez różnicy, czy o lewicowym, czy prawicowym zabarwieniu. Ideologiczna wizja świata ma fatalną właściwość klasyfikowania ludzi, szufladkowania ich, przylepiania im etykiety, obecnie mniej więcej: „uchodźcy”23.

Obecnie doświadczamy, jak postawy polityczne gwałtownie demonstrują swoją obecność, depcząc wszelką empatię, każde współczucie wobec konkretnej potrzeby poszczególnych osób. Uchodźcy są traktowani jako masa, która zagraża kulturowo, ekonomicznie czy politycznie, jako zagrożenie bezpieczeństwa, które stawia pod znakiem zapytania nasze obecne status quo - zapomina się przy tym, że każdy uchodźca ma in-

${ }^{22} \mathrm{Na}$ temat sprawiedliwości w wymiarze religijnym zob. hasło „sprawiedliwość Boża”, w: E. Ozorowski, Słownik podstawowych pojęć teologicznych, Warszawa 2007, s. $267-268$.

${ }^{23}$ Ważne i warte refleksji były wypowiedzi papieża Franciszka podczas Światowych Dni Młodzieży w Krakowie (2016). Zob. www.pope2016.com/sdm2016/wizyta-papieza/news,502500,sdm-cytaty-z-wystapien-papieza-franciszka-o-uchodzcachdokumentacja.html [dostęp: 06.12.2016]. 
dywidualną twarz, że ma własną historię cierpienia, a teraz rzeczywiście potrzebuje pomocy. Ideologia uogólnia - miłosierdzie widzi konkretnego człowieka w jego niedoli. To, że wówczas należy mądrze się zastanowić, jak tej potrzebie politycznie, administracyjnie i zgodnie z możliwościami zaradzić, wywołuje natychmiast ważne kolejne pytania, ale właśnie kolejne (np. te o europejską solidarność). I na takie pytania nie ma szybkich odpowiedzi ${ }^{24}$.

Tu znowu ukazuje się ważna rola, jaką wiara chrześcijańska odgrywa w obronie ideologicznego widzenia odosobnionego rozumienia sprawiedliwości. Jezus Chrystus przejął, jak powszechnie wiadomo, miłość Boga i bliźniego jako konwencjonalne zasady z religijnej tradycji swego ludu. To, co z pewnością pochodzi bezpośrednio od Niego, to znaczenie, jakie nadał tym dwom przykazaniom na tle innych wymagań Tory (całości prawodawstwa żydowskiego). On podporządkował te przykazania (nakazy) przykazaniu miłości (podobnie, jak w konstytucji lub tekście traktatu preambuła poprzedza wszelkie szczegółowe postanowienia Konstytucji lub umowy traktatowej i je interpretuje). Intencją Jezusa było pokazanie, że każda wrogość wobec człowieka, każdy brak miłosierdzia jest sprzeczny z intencją Jego Ojca w niebie. Wolą Boga bowiem jest zbawienie/wyzwolenie człowieka. Jego przynagla troska o człowieka, i w tej trosce o człowieka - brata każdy uczeń Jezusa powinien być podobny do miłosiernego Boga 25 .

Dochodzimy w tym punkcie do postawienia tezy: nasze społeczeństwo potrzebuje więcej niż tylko sprawiedliwości (!). Jak bardzo byłaby ona konieczna - na fundamencie sprawiedliwości potrzebuje nasz społeczny dom także miłosierdzia i solidarności wobec tych, którzy nie mogą poradzić sobie sami z życiem. Zwłaszcza w dziedzinie relacji międzyludzkich jest ważne, aby oprzeć się znieczulicy społecznej i tworzyć przestrzeń, w której człowiek może otrzymać miłość i ciepło. W tym zakresie, nawiasem mówiąc, otwiera się szerokie pole współpracy chrześcijan i nie-

${ }^{24}$ Szerzej na ten temat zob. Franciszek, Migranci i uchodźcy sa dla nas wyzwaniem. Odpowiedź daje Ewangelia miłosierdzia. Orędzie papieża Franciszka na Światowy Dzień Migranta i Uchodźcy 2016 r., Watykan 2015.

25 Zob. Kompendium nauki społecznej Kościoła, Kielce 2005, s. 138-139. 
chrześcijan. Można także odnieść wrażenie, że takie zaproszenie spotka się z pozytywnym odbiorem ${ }^{26}$.

Kościół od początku swego istnienia, odwołując się do tajemnicy Krzyża i zmartwychwstania, wypełnia przez swoją działalność misję Chrystusa. Współcześni chrześcijanie wyrażają pragnienie, żeby Jego przesłanie o miłości zbawiającej dotarło zwłaszcza do tych, których człowieczeństwo i godność zdają się zatracać w misterium iniquitatis. Kościół powinien zatem podjąć $\mathrm{z}$ nową mocą misję głoszenia orędzia o Bożym miłosierdziu, które może wlać w ludzkie serca nadzieję i stać się zarzewiem nowej cywilizacji - cywilizacji miłości ${ }^{27}$.

\section{PRZYKAZANIE MIŁOŚCl BLIŹNIEGO}

Poprzez swoje świadectwo o życiu Chrystusa Kościół umożliwia ludziom poznanie Tego, który w sposób doskonały wcielił w swym ziemskim życiu „największe przykazanie”28, zapowiedziane przez Niego samego $^{29}$. Dokonał tego w podwójnym wymiarze. Swoim życiem i śmiercią Jezus Chrystus wypowiedział bowiem, co to znaczy miłować Boga „nade wszystko" w tej postawie szacunku i posłuszeństwa wobec Ojca. Chrystus potwierdził też i urzeczywistnił w sposób doskonały przykazanie miłości bliźniego, poprzez którą określał swą misję i zgodnie z którą działał ${ }^{30}$.

Ewangelia Chrystusa jest przede wszystkim świadectwem miłości, gdyż wyraźnie pokazuje osobę Jezusa, który kochał ${ }^{31}$. W ewangeliach jest

${ }^{26}$ Zob. R. Forycki, Miłosierdzie nakazem sprawiedliwości, „Communio” 1-2 (1981), s. 77-86.

${ }^{27}$ Por. Jan Paweł II, Homilia podczas Mszy św. beatyfikacyjnej, Kraków 18 VIII 2002, 3 .

28 Por. Mt 22,38-40.

${ }^{29}$ Zob. E. Robek, Miłość zbawcza w Kościele i w świecie. Studium teologicznopastoralne $w$ świetle nauczania Jana Pawła II, Warszawa 2006, s. 275-288.

${ }^{30}$ Miłość Chrystusa do Ojca pozwalała Mu głosić: „Moim pokarmem jest wypełnić wolę Tego, który Mnie posłał i wykonać Jego dzieło” (J 4,34). Syn Człowieczy „nie przyszedł, aby Mu służono, lecz aby służyć i dać swoje życie na okup za wielu” (Mt 20,28). Jan Paweł II, Katecheza Świadectwo życia w Chrystusie w Kościele - wspólnocie prorockiej, $20 \mathrm{~V}$ 1992, 5.

${ }^{31}$ Podczas rozmowy z młodzieńcem, który pytał Go, co ma czynić, by osiągnąć 
wiele opisów Chrystusa, który uzdrawiał chorych na różne niemoce. ${ }^{32}$ Jezus także uzdrawiał przez „wyrzucanie złych duchów”33, co stało się powodem zarzutu, że czyni to z pomocą złego ducha. Chrystus odpowiadał na to oskarżenie, wykazując wewnętrzny nonsens takiego zarzutu: „Lecz jeśli Ja mocą Ducha Bożego wyrzucam złe duchy, to istotnie przyszło do was królestwo Boże"34.

Miłość bliźniego objawia się na zewnątrz w konkretnych działaniach, ale jej głównym celem jest wydawać duchowe owoce ${ }^{35}$. Ta moc miłości płynie od Ducha Świętego, który uzdalnia do przestrzegania przykazania miłości bliźniego: „abyście się nawzajem miłowali, tak jak Ja was umiłowałem”36. Jan Paweł II podkreśla, że w słowach: „tak jak Ja was umiłowałem" zawiera się nowa wartość miłości nadprzyrodzonej będącej udziałem w miłości Chrystusa do ludzi, a zatem w Miłości przedwiecznej, w której cnota miłości ma swój prawdziwy początek. Wyjaśnia to św. Tomasz z Akwinu, który pisze: „Sama natura Boga jest miłością, jak

królestwo niebieskie, „Jezus spojrzał z miłością na niego” (Mk 10,21). Natomiast św. Jan ewangelista zapisał, że "Jezus miłował Martę i jej siostrę, i Łazarza” (J 11,5), a samego siebie nazywa uczniem, „którego Jezus miłował” (J 13,23). Jezus kochał dzieci: „Przynosili $\mathrm{Mu}$ również dzieci, żeby ich dotknął (...). I biorąc je w objęcia, kładł na nie ręce i błogosławił je” (Mk 10,13.16). A ogłaszając przykazanie miłości, powołał się na tę miłość, którą On sam umiłował: „To jest moje przykazanie, abyście się wzajemnie miłowali, tak jak Ja was umiłowałem” (J 15,12). Jan Paweł II, Katecheza „We wszystkim do nas podobny oprócz grzechu”, 3 II 1988, 7.

${ }^{32} \mathrm{~Np}$. uzdrowienie niewiasty porażonej, która „w żaden sposób nie mogła się wyprostować” (por. Łk 13,10-16).

33 „Dlatego że Bóg był z Nim, przeszedł On (Chrystus) dobrze czyniąc i uzdrawiając wszystkich, którzy byli pod władzą diabła” (Dz 10,38).

${ }^{34}$ Zob. Mt 12,28; por. Łk 11,20. „Zaprawdę, zaprawdę, powiadam wam: Każdy, kto popełnia grzech, jest niewolnikiem grzechu. A niewolnik nie przebywa w domu na zawsze, lecz Syn przebywa na zawsze. Jeżeli więc Syn was wyzwoli, wówczas będziecie rzeczywiście wolni” (J 8,34-36). Wyzwalając ludzi od zła grzechu, Chrystus wielokrotnie demaskuje przy tym diabła, który jest „ojcem grzechu”. To właśnie od niego, od złego ducha, bierze początek „niewola grzechu”, w której znajdują się ludzie. Jan Paweł II, Katecheza Chrystus wyzwala człowieka do wolności w prawdzie, 3 VIII 1988, 3.

${ }^{35} \mathrm{~K}$. Gryz, Kształtowanie człowieczeństwa przez miłość. Idea wychowania w nauczaniu Jana Pawła II, w: Człowiek droga Kościoła. Moralne aspekty nauczania Jana Pawła II, dz. cyt, s. 205-248.

$36 \mathrm{~J} 13,34$. 
i mądrością, i dobrocią. I tak, skoro mówimy: dobrzy dobrocią, którą jest Bóg, czy mądrzy mądrością, którą jest Bóg - gdyż dobroć, której treścią dobrzy jesteśmy, jest pewnego rodzaju uczestnictwem w Bożej dobroci, a mądrość, której treścią jesteśmy mądrzy, jest pewnego rodzaju uczestnictwem w mądrości Bożej - tak też i miłość, której treścią miłujemy bliźniego, jest swego rodzaju uczestnictwem w miłości Bożej”. ${ }^{37}$ To uczestnictwo jest dziełem Ducha Świętego, który daje ludziom zdolność kochania nie tylko Boga, ale także bliźniego, tak samo jak umiłował go Jezus Chrystus. Skoro bowiem miłość Boża została rozlana w sercach chrześcijan, to dzięki niej mogą kochać ludzi, a także w jakimś sensie stworzenia bezrozumne, tak jak kocha je Bóg.

\section{SPRAWIEDLIWOŚĆ UGRUNTOWANA W MIŁOŚCI}

Chrystus, jako człowiek prawdziwie i straszliwie cierpiący, zwraca się w Ogrójcu i na Kalwarii do Ojca, którego miłość głosił ludziom, o którego miłosierdziu świadczył całym swoim postępowaniem ${ }^{38}$. Z woli Boga nie zostaje $\mathrm{Mu}$ jednak oszczędzone straszne cierpienie. Odkupienie w tym wymiarze jest ostatecznym i definitywnym objawieniem się świętości Boga, który jest bezwzględną pełnią doskonałości, pełnią sprawiedliwości i miłości przez to, że sprawiedliwość ugruntowana jest w miłości, wyrasta z niej niejako i ku niej zmierza.

W męce i śmierci Chrystusa, w tym, że Ojciec własnego Syna nie oszczędził, ale uczynił Go grzechem za nas, znajduje swój wyraz absolutna sprawiedliwość, gdyż męki i krzyża doznaje Chrystus ze względu na grzechy ludzkości. Jest to wręcz jakiś „nadmiar” sprawiedliwości, gdyż grzechy człowieka zostają „wyrównane” ofiarą Boga - Człowieka. Jednakże ta sprawiedliwość, która prawdziwie jest sprawiedliwością „na miarę" Boga, całkowicie rodzi się z miłości: z miłości Ojca i Syna, i całkowicie owocuje w miłości. Właśnie dlatego owa sprawiedliwość Boża objawiona w krzyżu Chrystusa jest „na miarę Boga”, że rodzi się z miłości i w miło-

37 Zob. M. Graczyk, Miłość miłosierna zasada życia chrześcijańskiego, „Studia Theologica Varsaviensia" 31 (1993)1, s. 189-196.

38 Por. D. von Hildebrand, Serce, Poznań 1985, s. 186. 
ści dopełnia się, rodząc owoce zbawienia. Boski wymiar Odkupienia nie urzeczywistnia się w samym wymierzeniu sprawiedliwości grzechowi, ale w przywróceniu miłości, tej twórczej mocy w człowieku, dzięki której ma on znów przystęp od owej pełni życia i świętości, jaka jest z Boga. W ten sposób Odkupienie niesie w sobie całą pełnię objawienia miłosierdzia ${ }^{39}$.

Miłosierdzie jest $\mathrm{z}$ pewnością wielkim tematem teologicznym papieża Franciszka. Przy bliższym przyjrzeniu się jednak jest to temat łączący nauczanie papieża Franciszka, papieża Benedykta XVI i papieża Jana Pawła II ${ }^{40}$. Wszyscy oni przypominają w swoim nauczaniu kluczowy, podstawowy motyw tradycji chrześcijańskiej, a także katolickiej nauki społecznej: bez miłości i miłosierdzia nie ma chrześcijaństwa!

Kościół głosi miłosierdzie Boga i zachęca ludzi do miłosierdzia. Ale to wezwanie do miłosierdzia rodzi pewne wewnętrzne konflikty. Ponadto Miłosierdzie jest przez wiele różnych środowisk w społeczeństwie i w Kościele podawane w wątpliwość: to ideologia niekonsekwentnych i bojących się konfliktów; ono indywidualizuje solidarność i zsyła potrzebujących na łaskę samowoli bogatych; Miłosierdzie upokarza adresatów i ostatecznie jest niesprawiedliwe. W obliczu tej powszechnej krytyki miłosierdzia wyzwaniem dla całego Kościoła jest trwanie mocno w wierze w Boga, która została objawiona w Jezusie Chrystusie. Z tą intencją muszą zostać przezwyciężone także redukcje w rozumieniu miłosierdzia, które często są spowodowane problematycznym przeciwstawianiem miłosierdzia sprawiedliwości ${ }^{41}$.

\section{JEDNOŚĆ MIŁOSIERDZIA I SPRAWIEDLIWOŚCI W BOGU}

Tylko ten, kogo Bóg wezwie, może zrozumieć ostatecznie nieograniczone możliwości człowieka. Odnosi się to również do właściwego rozumienia miłosierdzia i jego stosunku do sprawiedliwości. Tę perspektywę ukazuje także papież Franciszek, gdy pisze w bulli ogłaszającej Rok Święty miłosierdzia: „Ono [miłosierdzie] stało się żywe, widoczne i osiągnęło

39 DiM 7.

40 Zob. m.in. encykliki: Dives in misericordia, Deus caritas est, Evangelii gaudium.

${ }^{41}$ Por. Benedykt XVI, Deus caritas est, Encyklika o miłości chrześcijańskiej, Watykan 2005, nr 26. 
swój szczyt w Jezusie z Nazaretu"42. Niepowtarzalna jest uwaga Boga skierowana do człowieka, gdyż on sam stał się człowiekiem i jednocześnie pozostał Bogiem. Bóg stał się prawdziwym człowiekiem, doświadczył najbardziej ekstremalnych przeżyć, jakie są udziałem ludzi - ból, cierpienie, nawet opuszczenie przez Boga i śmierć. Ponieważ Bóg okazał się wierny wobec swojego Syna, a w Nim nam i wskrzesił go trzeciego dnia z martwych, ukrzyżowanie Jezusa Chrystusa jest ekstremalną formą miłosierdzia. W śmierci bowiem swojego Syna daje z miłości miłosiernej wszystko! Miłosierdzie Boga zostało objawione w zmartwychwstaniu i obiecane wszystkim ludziom ${ }^{43}$.

Ta obietnica zostanie spełniona dopiero na sądzie ostatecznym. Wszechmocny, pełen dobroci Bóg - tak wierzymy i taką mamy nadzieję - będzie łaskawy w swym osądzie, bez faworyzowania lub gnębienia kogokolwiek. Łaska Boża jest tak bogata, że może być zrozumiała tylko poza ludzką logiką podziału dóbr deficytowych. To, co zostało przyznane komuś, nie musi zostać zabrane innemu w niebie. Na końcu czasów okaże się w całej pełni, że miłosierdzie Boże i Jego sprawiedliwość nie ograniczają się wzajemnie, lecz wypełniają. Walter Kasper mówi, spoglądając do Biblii, że „miłosierdzie jest Boga własną sprawiedliwością”44.

Ponieważ Bóg jest miłosiernym Bogiem, pozwala nam mieć udział w jego miłosierdziu i sprawiedliwości. To jest przede wszystkim łaska, dar, który możemy przyjąć w wolności i odpowiedzialności, a która powinna być realizowana w naszym dążeniu do sprawiedliwości i miłosierdzia. Ale: Nie jesteśmy bogami! Różnica między nieskończonym Bogiem i skończonym człowiekiem pozostaje. Nawet w wierze i głębokiej ufności w miłość Boga ludzie nie mogą o własnych siłach zrównoważyć miłosierdzia i sprawiedliwości. Jednakże w świetle wiary obie te zasady podstawowe mogą się uzupełniać i wzmacniaćc 45 .

Dla papieża Franciszka miłosierdzie jest ważne dla całej równowagi Kościoła: „Architrawem, na którym wspiera się życie Kościoła, jest miłosierdzie. Wszystko w działaniu duszpasterskim Kościoła powinno być

${ }^{42}$ MV 1.

${ }^{43}$ Por. Jan Paweł II, Dives in misericordia, dz. cyt., nr 2.

${ }^{44}$ Por. W. Kasper, Barmherzigkeit, dz. cyt., s. 27.

45 Zob. Jan Paweł II, Sąd i miłosierdzie. Audiencja generalna z 7 lipca 1999 r., „L'Osservatore Romano” 1999, nr 9-10, nr 1. 
przepojone czułością, z którą kieruje się do wiernych; w tym, co głosi i o czym daje świadectwo światu, nie może nigdy brakować miłosierdzia"46. W wierze chrześcijańskiej miłosierdzie i sprawiedliwość przynależą razem. W życiu ludzi miłosierdzie i sprawiedliwość pozostają w jedności, cechującej się jednak pewnymi napięciami. To czyni życie bogatszym zamiast sugerować harmonię, której przecież być jeszcze nie może. Jak sprawiedliwość i miłosierdzie są atrybutami Boga i nie wykluczają się wzajemnie, lecz uzupełniają i doskonalą, tak postawa miłosierdzia prowadzi do większej sprawiedliwości.

Streszczenie. Miłosierdzie chrześcijańskie i sprawiedliwość społeczna nie są sobie przeciwstawne, ale mają charakter komplementarny. Zadaniem obu jest przecież służba człowiekowi. Obie wartości mają za przedmiot dobro osoby, lecz dla sprawiedliwości dobro jest przede wszystkim przedmiotem, który należy w sposób właściwy rozdzielić, natomiast przedmiotem miłości jest dobro bliźniego bez podziałów i ograniczeń. W działaniu obie cnoty uzupełniają się, a zatem chrześcijanie powinni postępować sprawiedliwie i z miłością. Oprócz sprawiedliwości współczesny świat potrzebuje miłosierdzia, potrzebuje miłości, która chce zwyczajnie dobra dla bliźniego - nawet wówczas, gdy nie otrzyma żadnego wynagrodzenia i żadna sankcja prawna jej nie egzekwuje. Jak cenna może być łaska, litość i zmiłowanie, każdy może sobie najlepiej powiedzieć, gdy wyobrazi sobie siebie w rękach bezwzględnego człowieka. Miłość bliźniego objawia się na zewnątrz w konkretnych działaniach, ale jej głównym celem jest wydawać duchowe owoce. Ta moc miłości płynie od Ducha Świętego, który uzdalnia do przestrzegania przykazania miłości bliźniego: „abyście się nawzajem miłowali, tak jak Ja was umiłowałem”.

Słowa kluczowe: miłość; miłosierdzie; sprawiedliwość; przymioty Boga; nawrócenie; posługa Kościoła.

Abstract. Complementary character of Christian mercy and social justice in the mission of Church as a teacher, depository and dispenser of mercy. Christian mercy and social justice are not contradictory, indeed they are complementary. This is only too natural as both are targeted at serving people. Either is aimed at ensuring man's welfare. Still, whereas for justice the welfare is primarily the object which should be appropriately distributed, the object of love is man's welfare without any divisions and restrictions. In daily life both virtues are thus complementary which means that Christians should act in every situation following both the principles of justice and love. Apart from justice the modern world needs mercy; it needs love which is simply acting on behalf of the welfare of one's neighbour and fellowman even if it brings no reward and is not imposed 
by any legal sanction. Only the man who has found himself in the in the hands of an unscrupulous man can say how precious is the value of grace, mercy and empathy. Love of one's neighbour is revealed in all specific activities but its chief goal is to bring spiritual fruits. This power of love flows from the Holy Ghost which enables us to observe the commandment of love of one's neighbour. It is best expressed in the words, "Love one another as I have loved you."

Key words: love; mercy; justice; Divine attributes; conversion; service of the Church.

\section{BIBLIOGRAFIA}

Benedykt XVI, Deus caritas est. Encyklika o miłości chrześcijańskiej, Watykan 2005.

Benedykt XVI, Godność człowieka, wspólne dobro, pomocniczość i solidarność. Przemówienie do uczestników sesji plenarnej Papieskiej Akademii Nauk Społecznych. Rzym, 3 maja 2008 r.

Forycki R., Miłosierdzie nakazem sprawiedliwości, „Communio” 1-2 (1981), s. 77-86.

Franciszek, Evangelii Gaudium. Adhortacja na zakończenie Roku Wiary, Watykan 2013.

Franciszek, Laudato Si. Encyklika poświęcona trosce o wspólny dom, Watykan 2015.

Franciszek, Migranci i uchodźcy sa dla nas wyzwaniem. Odpowiedź daje Ewangelia miłosierdzia. Orędzie na Światowy Dzień Migranta i Uchodźcy 2016 r., Watykan 2015.

Franciszek, Misericordiae vultus. Bulla ustanawiająca nadzwyczajny Jubileusz Miłosierdzia, Watykan 2015.

Franciszek, wybór cytatów: www.pope2016.com/sdm2016/wizyta-papieza/news,502500,sdm-cytaty-z-wystapien-papieza-franciszka-o-uchodzcach-dokumentacja.html [dostęp: 06.12.2016].

Graczyk M., Miłość miłosierna zasada życia chrześcijańskiego, „Studia Theologica Varsaviensia” 31 (1993)1, s. 189-196.

Gryz K., Kształtowanie człowieczeństwa przez miłość. Idea wychowania w nauczaniu Jana Pawła II, w: Człowiek droga Kościoła. Moralne aspekty nauczania Jana Pawła II, Kraków 2004, s. 205-248.

Hildebrand D. von, Serce, Poznań 1985.

Jan Paweł II, Chrystus wyzwala człowieka do wolności w prawdzie. Katecheza z 3 VIII 1988, 3 .

Jan Paweł II, Dives in misericordia. Encyklika o Bożym miłosierdziu, Watykan 1980.

Jan Paweł II, Homilia podczas Mszy św. beatyfikacyjnej, Kraków 18 VIII 2002, 3.

Jan Paweł II, Sąd $i$ miłosierdzie. Audiencja generalna z 7 lipca 1999 r., „L'Osservatore Romano" 1999, nr 9-10, nr 1.

Jan Paweł II, Świadectwo życia w Chrystusie w Kościele - wspólnocie prorockiej. Katecheza z $20 \mathrm{~V}$ 1992, 5. 
Jan Paweł II, „We wszystkim do nas podobny oprócz grzechu”. Katecheza z 3 II 1988, 7. Kasper W., Barmherzigkeit. Grundbegriff des Evangeliums - Schlüssel christlichen Lebens, Freiburg i. Br. 2012.

Kompendium nauki społecznej Kościoła, Kielce 2005, s. 138-139.

Krajski S., Dzieci Abrahama. I sprawiedliwość, i miłosierdzie, „Więź” 2016, nr 2, s. 74-80.

Matwiejuk K., Bóg bogaty $w$ miłosierdzie w świetle pierwszej modlitwy eucharystycznej o tajemnicy pojednania, „Warszawskie Studia Teologiczne” 2016, nr 2, s. 24-37.

Ozorowski E., Słownik podstawowych pojęć teologicznych, Warszawa 2007, s. 267-268.

Robek E., Miłość zbawcza w Kościele i w świecie. Studium teologicznopastoralne $w$ świetle nauczania Jana Pawła II, Warszawa 2006.

Romaniuk K., Biblijny traktat o miłosierdziu, Ząbki 2004.

Shakespeare W., Kupiec wenecki, tł. S. Barańczak, Kraków 2004.

Söding T., Die Verkündigung Jesu - Ereignis und Erinnerung, Freiburg i. Br. 2011.

Wywiad z papieżem Franciszkiem dla czasopism jezuickich przeprowadzony przez Antonio Spadaro SJ 19 sierpnia 2013 r., www.stimmen-der-zeit.de/zeitschrift/ online_exklusiv/details_html?k_beitrag=3906412 [dostęp: 06.12.2016]. 